\title{
Mature Pericardial Teratoma
}

National Cancer Institute

\section{Source}

National Cancer Institute. Mature Pericardial Teratoma. NCI Thesaurus. Code C6744.

A mature teratoma that arises from the pericardium. 